\title{
Hydrocarbon Potential of the Triassic Lacustrine Source Rocks in the Newark Basin, USA
}

\author{
Larbi Rddad \\ Earth and Planetary Division, Physical Sciences Department, Kingsborough Community College, City University of New York, New York, \\ USA
}

Email address:

Lrddad@gmail.com

\section{To cite this article:}

Larbi Rddad. Hydrocarbon Potential of the Triassic Lacustrine Source Rocks in the Newark Basin, USA. Journal of Energy, Environmental \& Chemical Engineering. Vol. 4, No. 4, 2019, pp. 47-53. doi: 10.11648/j.jeece.20190404.11

Received: October 30, 2019; Accepted: November 18, 2019; Published: November 22, 2019

\begin{abstract}
This study investigates the hydrocarbon potential of the organic matter-rich Triassic rocks of the Newark basin in the USA. The development of anoxic conditions during the Late Triassic led to the accumulation and preservation of the organic matter during the deposition of the Lockatong formation in a lacustrine setting. The total organic carbon (TOC) values of the black shale samples from the Nursery and Titusville cores of this formation range from 0.50 to $2.72 \%$ (avg. $=1.2 \%$ ), indicating a fair to good source rock. On the Hydrogen Index (HI) vs the Oxygen Index (OI) diagram, the studied samples plot at the end of the evolutionary paths of kerogen types I, II, and III. This indicates that the organic matter is overmature and is in the dry gas window. This degree of maturity is also consistent with the $\mathrm{T}_{\max }$ values ranging from $506^{\circ} \mathrm{C}$ to $547^{\circ} \mathrm{C}$ and is confirmed by published vitrinite reflectance values $\left(\% \mathrm{R}_{\mathrm{o}}\right)$ which vary between 1.95 and $2.69 \%$. This overmaturity is the result of an active subsidence during the Late Triassic-early Jurassic in relation with the reactivation with the deep-seated regional NE-SW-trending faults. Although the overmaturity of the organic matter renders the identification of the type of organic matter difficult, the organic matter is likely kerogen II-III type. On the basis of the available data, it is concluded that this formation has no generative liquid hydrocarbon potential.
\end{abstract}

Keywords: Source Rock, Lockatong Formation, Organic Matter, Hydrocarbon Potential, Newark Basin

\section{Introduction}

The geology of the Newark basin has been studied by numerous geologists [1-4]. During 1980's, the Early Mesozoic basin program was launched by US Geological survey to assess the distribution and richness of organic matter in outcrops, and the hydrocarbon potential of this eastern Mesozoic basin. The Newark basin was one of the targeted basins owing to organic matter-rich Triassic and Jurassic formations. The Jurassic formations were found to be good source rocks for hydrocarbons and their organic matter content reached the oil window $[5,6]$. The hydrocarbon potential of the Triassic rocks that cropped out in the Hartford and Newark basins were assessed [7]. These authors reached the conclusion that the Triassic rocks in Harford basin are thermally mature with respect to petroleum generation. With the availability of $6770 \mathrm{~m}$ of a core from the Newark Basin Coring Project (NBCP), it is possible to thoroughly evaluate the hydrocarbon potential of the Newark basin. The present study characterizes the quantity and quality of the black shale of the Triassic Lockatong Formation. Total organic carbon (TOC) is analyzed to evaluate the richness of organic matter and the maturity of the organic matter is assessed through the Rock-Eval technique. The quality of organic matter (Type I, II, and or III Kerogen) is also attempted.

\section{Geological Background of the Newark Basin}

The early Mesozoic Newark basin is one of the most studied Newark supergroup rift basins in the northeastern United States (Figure 1). The Newark basin is an elongated half-graben over of $190 \mathrm{~km}$ long and up to $50 \mathrm{~km}$ across [2]. The Precambrian and early Paleozoic rocks representing the southwestern Appalachian part of the New England upland border the Newark basin to the Northeast. To the southeast, 
the basin is bordered by the Paleozoic and Precambrian Appalachian highlands of the Blue Ridge and Piedmont Provinces [8]. The Appalachian highlands are the result of collisions between the North American continent and various Gondwanan fragments, including Africa, during the Paleozoic, leading to the formation of the supercontinent Pangea [9].

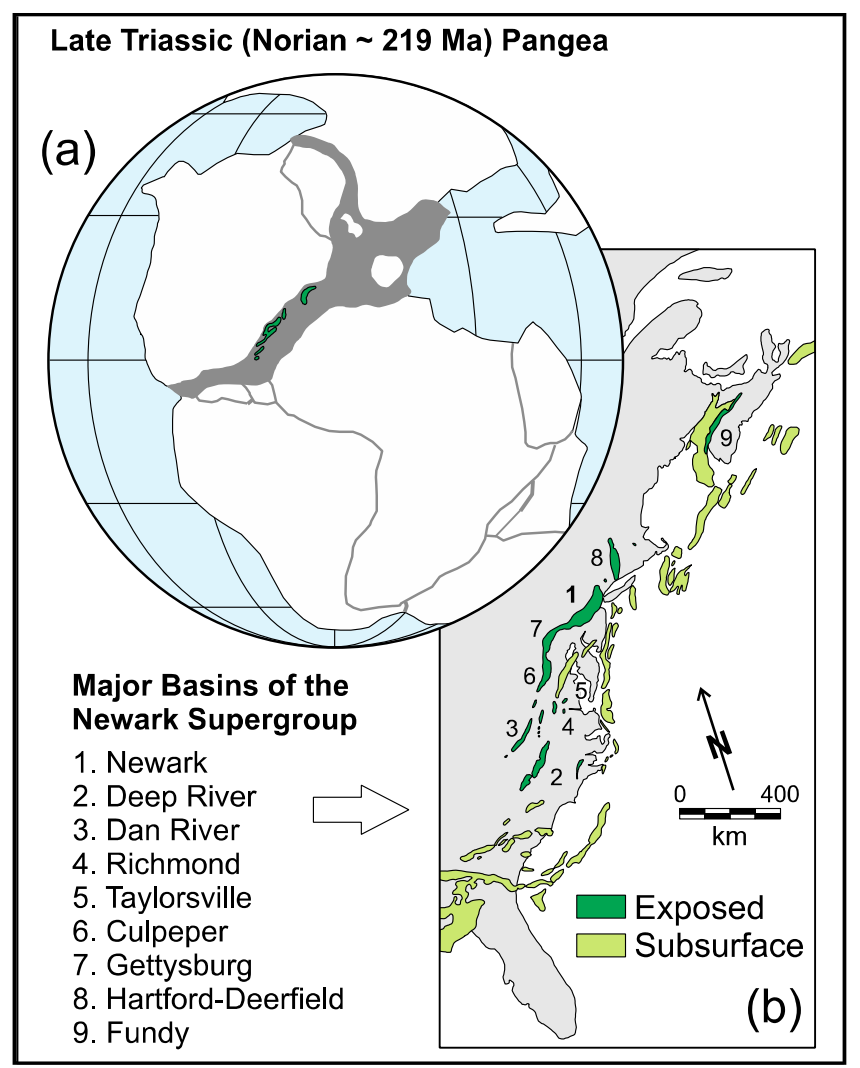

Figure 1. (a) Reconstruction of Pangea for the middle Norian showing the zone of early Mesozoic rifting (shaded) and the preserved basins of the Newark Supergroup (green). (b) Early Mesozoic rift basins of eastern North America.

The Newark rift basin formed during the break-up of Pangea and the opening of the Atlantic Ocean [10]. During this continental rifting, the Triassic-Jurassic extensional tectonic activity led to the reactivation of Paleozoic NE-SWtrending major faults, and subsequently the formation of a half-graben [3, 4]. This basin was filled with 6 to $8 \mathrm{~km}$ of non-marine, fluvio-lacustrine sediments intercalated with few basaltic flows [2]. These non-marine sediments derived from the weathering and erosion of the surrounding Precambrian and Paleozoic highlands [11]. The latter consisted mainly of granitic gneiss, schists, and minor mafic rocks [12]. Overlying the Precambrian-Paleozoic basement are the Triassic-Jurassic fluvio-lacustrine formations [2], which are listed and briefly described below from oldest to youngest:

1. Stockton Formation $\left(\begin{array}{lll}1800 & \mathrm{~m}\end{array}\right)-$ consists of alluvial/fluvial arkosic and sandstone facies.

2. Lockatong Formation (1000 - $2000 \mathrm{~m})$ - mainly consists of cyclic organic matter-rich black shales and gray to red mudstone, siltstone, and sandstone facies with intercalations of argillaceous carbonates [1, 2].

3. Passaic Formation $(2800 \mathrm{~m})$ - mainly consists of red mudstones and sandstone containing evaporites with few lacustrine black shale levels.

4. Jurassic formations $(300-400 \mathrm{~m})$ - The Feltville, Towaco, and Boonton formations consist of detrital lacustrine sedimentary rocks intercalated with basaltic flows and intrusive diabase.

The Post-rift inversion, tilting, and erosion led to the current extent of the present-day Newark basin [13].

\section{Lithostratigraphic Description of the Studied Cores}

The samples for this study were collected from the Walls Islands Member and the Byram Member which, represent the upper and lower organic matter- rich sections of the Lockatong Formation, respectively (Figure 2). Two cores were chosen for this project: the Titusville and Nursery cores (Figure 2).

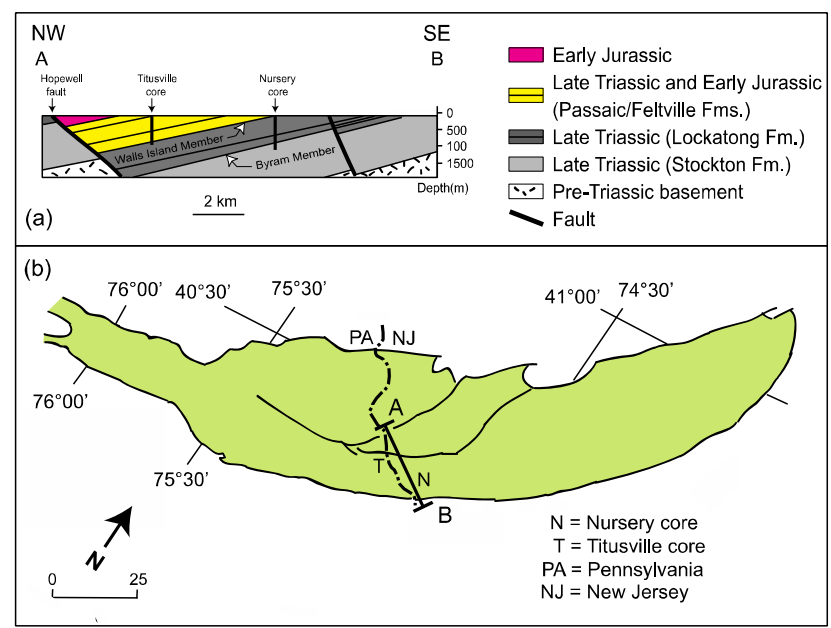

Figure 2. Geologic cross section $A-B$ in the Newar basin showing the Titusville and Nursery cores (A) and location of $A-B$ cross section in the Newark basin (B) (after [2]) with permission).

These cores represent part of $6770 \mathrm{~m}$ of core obtained from the Newark Basin Continental Drilling Project (NBCDP). The Walls Island and Byram members, described in Figures 3 and 4, consist mainly of black shale intercalated with gray to light gray shale and pinkish-gray shale. This succession reflects the development of small-scale anoxic events (black shale) separated by oxic to suboxic events (light gray to pinkish-gray shale). The black shale, typically rich in organic matter, contain pyrite that occurs as disseminated, euhedral to subhedral, millimeter- to centimeter-size crystals, and as small horizontal veins. The light gray to pinkish-gray shales commonly host numerous bitumen- filled fractures typically associated with calcite. 


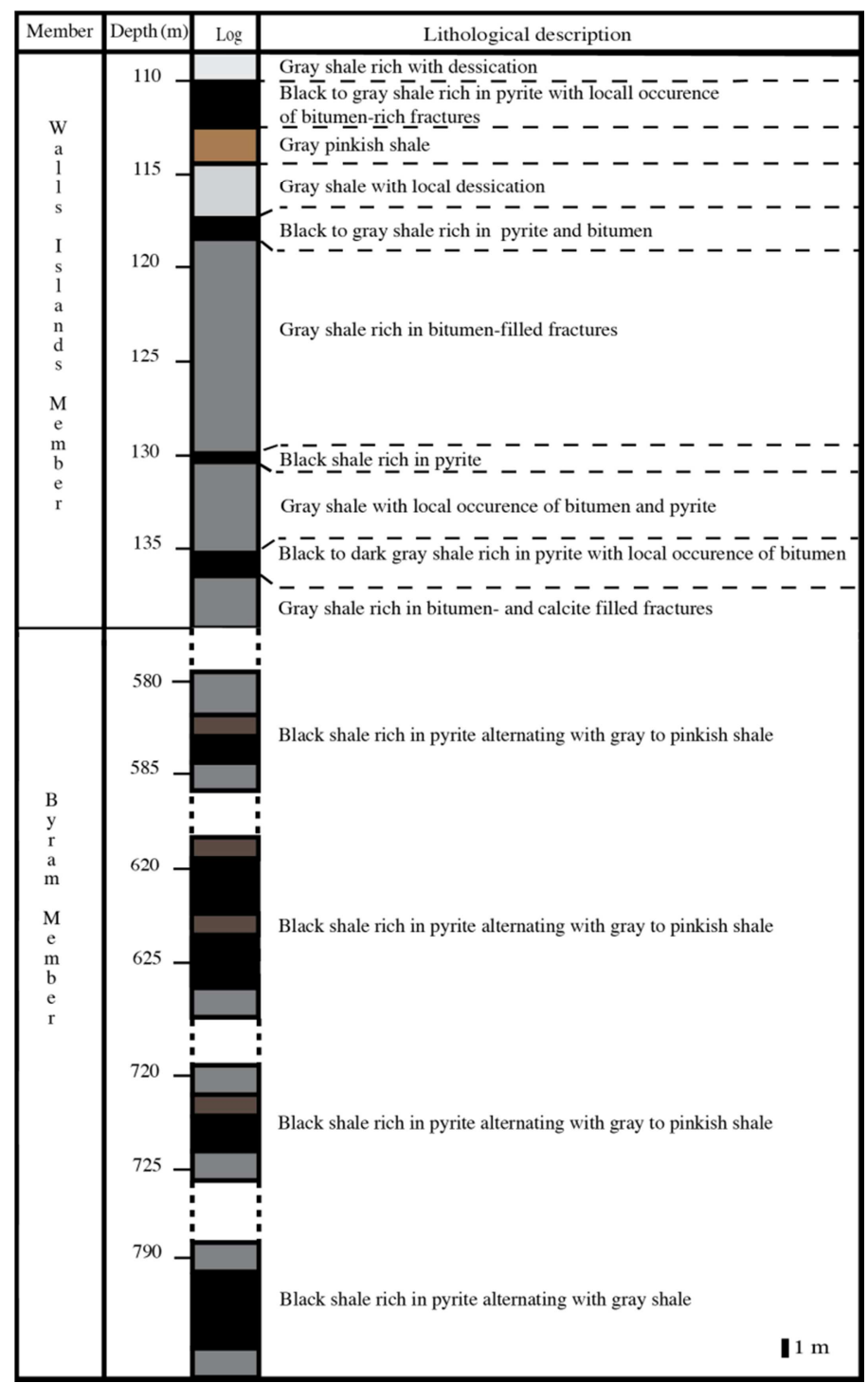

Figure 3. Log of the Walls Island Member and the Byram Member of the Lockatong Formation in the Nursery core, Newark basin.

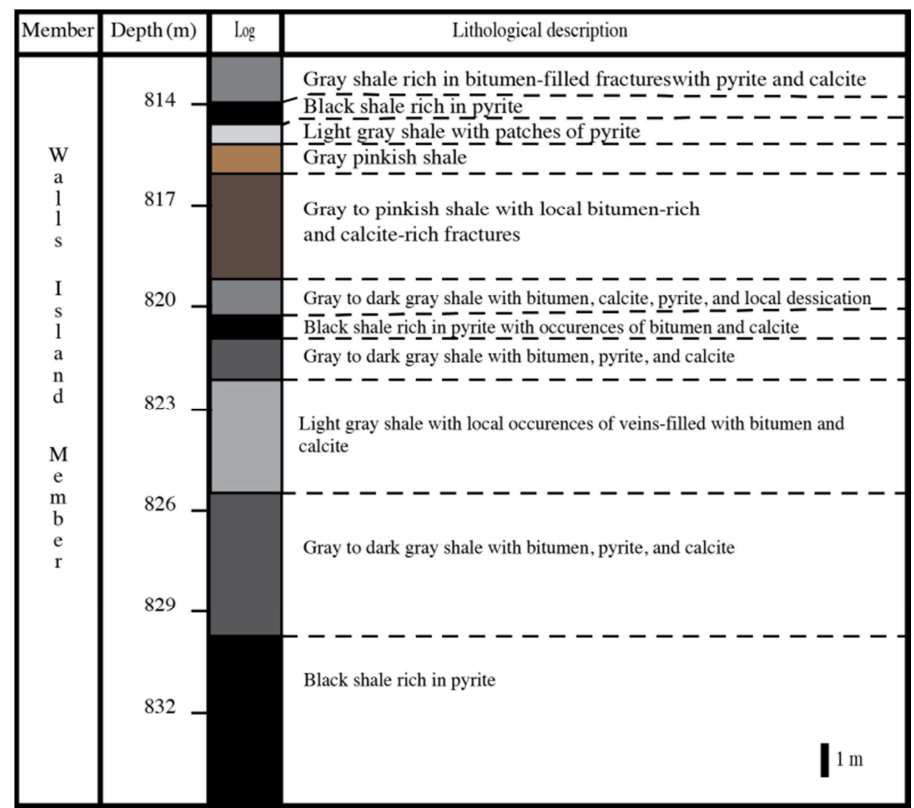

Figure 4. Log of the Walls Island Member of the Lockatong Formation in the Titusville core, Newark basin. 


\section{Sampling and Method}

A total of twelve black shale samples were collected from the Nursery and Titusville cores at different depths in the Lockatong Formation (Figure 2). The total organic carbon (TOC) analysis of the black shales using the Rock-Eval technique was performed at Acta Laboratories. The COrganic is calculated according to the following: C-Organic $=$ Total $\mathrm{C}-\mathrm{C}_{\mathrm{CO} 2}-\mathrm{C}_{\text {Graphitic }}$. Rock-Eval 6 programmed pyrolysis was performed at Weatherford Laboratories. The reader is referred to a detailed description of the Rock-Eval technique [14]. Pyrolyzed hydrocarbons and carbon dioxide were measured as a function of temperature, where $S_{1}$ represents free hydrocarbons in the kerogen, and $S_{2}$ represents pyrolyzable hydrocarbons generated by pyrolysis and related to the petroleum-generating potential of the sediment. $\mathrm{S}_{2}$ is normalized to TOC to calculate the hydrogen index $(\mathrm{HI})$, which is proportional to the kerogen elemental $\mathrm{H} / \mathrm{C}$ ratio. In a similar way, the pyrolyzable $\mathrm{CO}_{2}$ was measured and normalized to TOC to determine the oxygen index (OI), which is sometimes proportional to the kerogen elemental $\mathrm{O} / \mathrm{C}$ ratio. The $\mathrm{S}_{3}$ value expresses the milligrams of carbon dioxide produced from a gram of rock during temperature programming up to $390^{\circ} \mathrm{C} . \mathrm{T}_{\max }$ is the temperature at the maximum of the $\mathrm{S}_{2}$ peak.

\section{Results and Discussion}

\subsection{Quantity Evaluation}

Total organic carbon (TOC) is a good indication of the organic matter richness of source rocks. The TOC values vary between 0.5 and $2.1 \%$ and between 0.8 and $1.6 \%$ in Nursery and Titusville cores, respectively (Table 1, Figure 5A).
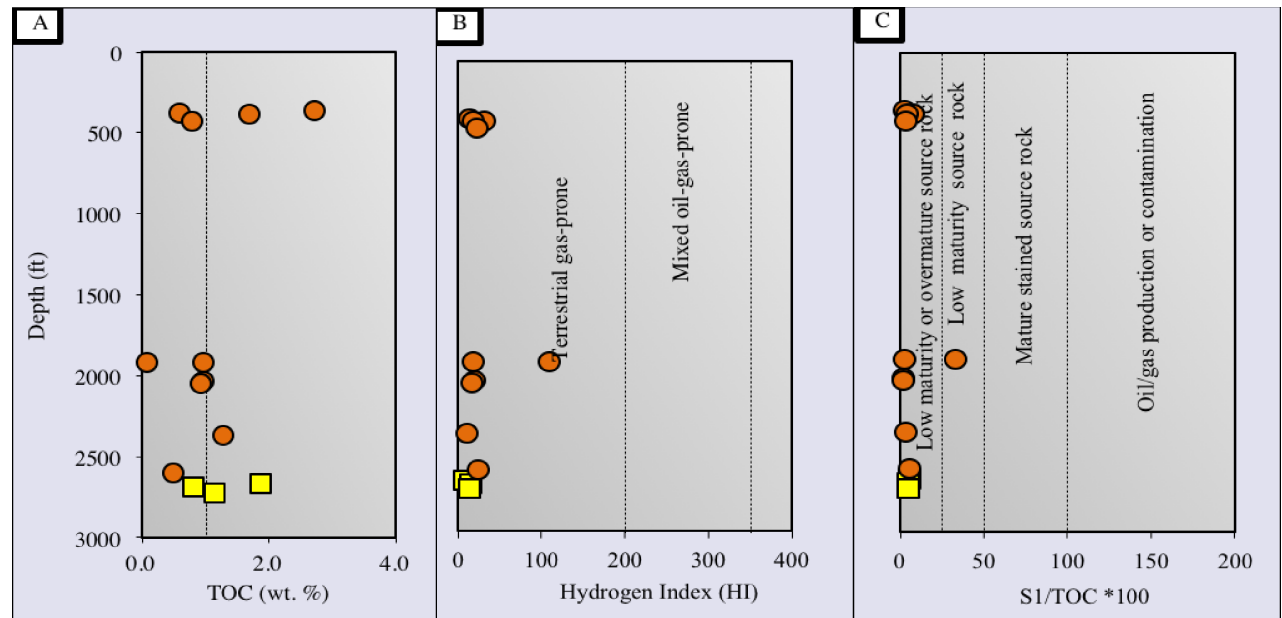

Figure 5. Plots of TOC vs depth (A), HI vs depth (B), and $S_{I} /$ TOC * 100 vs depth (C) in the Nursery (brown circles), and the Titusville (yellow squares) cores, Newark basin.

Table 1. Rock Eval data for the pyrolyzed black shale samples from the Nursery and Titusville cores, Newark basin. Detection limit for TOC is 0.5\%.

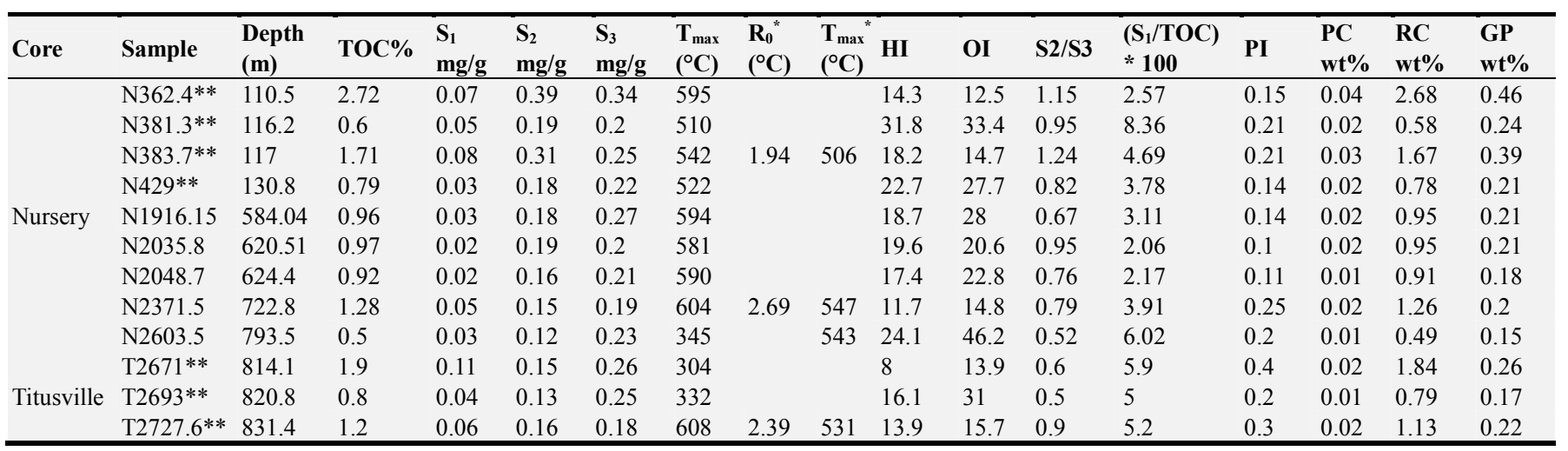

Notes: TOC: Total Organic Carbon, wt $\% ; \mathrm{S}_{1}$ : Volatile/free hydrocarbon $(\mathrm{HC}) ; \mathrm{S}_{2}$ : Remaining HC generative potential, mg HC/ g rock; $\mathrm{S}_{3}$ : Carbon dioxide content, mg $\mathrm{CO}_{2} / \mathrm{g}$ rock; $\mathrm{T}_{\max } *$ : Temperature of peak $\mathrm{S}$ maximum, ${ }^{\circ} \mathrm{C} ; \mathrm{R}_{\mathrm{o}} *$ : Vitrinite reflectance from [15]; $\mathrm{T}_{\max }$ : Calculated $\mathrm{T}_{\max }$ based on $\mathrm{R}_{\mathrm{o}}$ using $\mathrm{R}_{\mathrm{o}}+$ 7.16)/0.018 equation, ${ }^{\circ} \mathrm{C}$; HI: Hydrogen Index $=\left(\mathrm{S}_{2} \times 100\right) / \mathrm{TOC}, \mathrm{mg} \mathrm{HC} / \mathrm{g}$ TOC; OI: Oxygen Index $=\left(\mathrm{S}_{3} \times 100\right) / \mathrm{TOC}, \mathrm{mg} \mathrm{CO} 2 / \mathrm{g}$ TOC; PI: Production Index $=\mathrm{S}_{1} /\left(\mathrm{S}_{1}+\mathrm{S}_{2}\right)$; PC: Pyrolyzable Organic Carbon $=\left(\left(\mathrm{S}_{1}+\mathrm{S}_{2}\right) / 10\right)$ x 0.83, wt $\%$; RC: Residual Organic Carbon $=\mathrm{TOC}-\mathrm{PC}$, wt $\%$; GP: Genetic Potential= S1 + $\mathrm{S} 2 ; * *$ : Data from [16].

These values indicate that the black shales are relatively rich in organic matter and are considered as fair to a good source of hydrocarbons. The plot of the data on the TOC vs
$\mathrm{S}_{2}$ diagram, further confirms this conclusion (Figure 6). The overmaturity of organic matter may have reduced the TOC content. Hence, TOC values may be higher than $2.1 \%$. The 
organic matter-rich layers reflect anoxic conditions developed during the Late Triassic time. These anoxic conditions resulted in the accumulation and preservation of the organic matter preserved in the Lockatong Formation. This is consistent with the abundance of diagenetic bacteriogenic-derived pyrite which formed in an anoxic/euxinic environment (Figure 7) [16]. These anoxic events are separated by oxic to suboxic events marked by light gray to pinkish-gray shale layers [16].

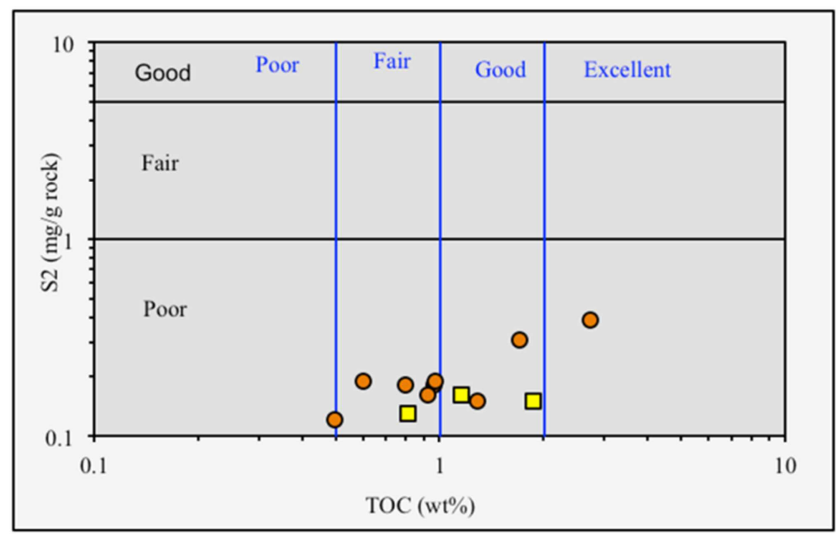

Figure 6. TOC vs $S_{2}$ in the Nursery (brown circles) and Titusville (yellow squares) cores, Newark basin.

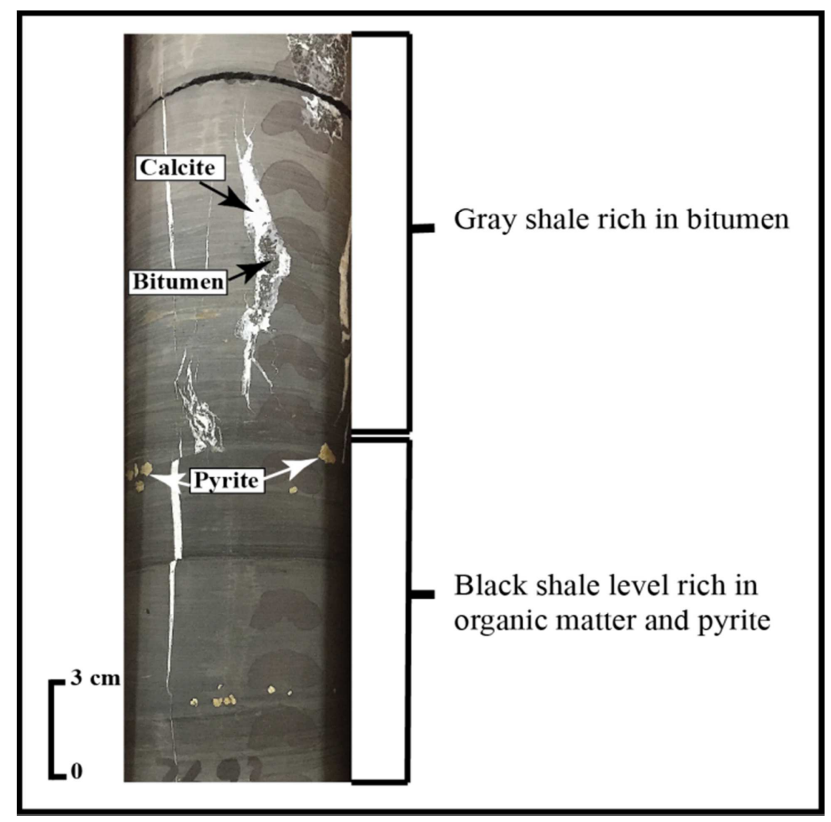

Figure 7. Alternating black shale rich in pyrite and gray shale rich in bitumen.

\subsection{Quality Evaluation and Organic Matter Maturity}

The Hydrogen Index (HI) versus Oxygen Index (OI) diagram provides information regarding the type of kerogen. The plot of the data in the HI vs OI diagram put the studied samples at the end of the evolutionary paths of Type I, II, and III (Figure 8). The position of the data is due to the overmaturity of organic matter. Based on HI values, the organic matter seems to be of type III (Figure 5B). However, it is difficult to determine the type of organic matter due to its overmaturity. The hydrogen index (HI) of the analyzed samples is less than $200 \mathrm{mg} \mathrm{HC} / \mathrm{g}$ TOC and is due to the organic matter maturity. The $\mathrm{T}_{\max }$ values are widespread $\left(304-608^{\circ} \mathrm{C}\right)$ and are unreliable due to the very low $\mathrm{S}_{2}$ values. Using Jarvies's equation $\mathrm{T}_{\max }=\left(\mathrm{R}_{0}+7.16\right) / 0.018$ [17]) and the available $\mathrm{R}_{0}$ data (1.94 to $2.69 \%$, [17]), the calculated $\mathrm{T}_{\max }$ range for measured vitrinite reflectance values is 506 $547^{\circ} \mathrm{C}\left(\mathrm{T}_{\max }\right.$ avg. $\left.=527^{\circ} \mathrm{C}\right)$ and $531^{\circ} \mathrm{C}$ for the Nursery and Titusville cores, respectively (Table 1). These $\mathrm{T}_{\max }$ values indicate that the organic matter of the analyzed samples is overmature with respect to liquid hydrocarbons. In fact, the variation of $\left(\mathrm{S}_{1} / \mathrm{TOC}\right) * 100$ ratio with TOC content in the Nursery core, which has enough data, shows a hyperbolic curve (Figure 9). This reveals the accumulation of free bitumen in the OM-relatively poor lithological facies and confirms the migration of the hydrocarbons from OM-rich black shales to OM-poor facies (Figure 7). Organic matter overmaturity is confirmed by the very low genetic potential $\left(\mathrm{GP}=\mathrm{S}_{1}+\mathrm{S}_{2}\right)$ values ranging from 0.15 to $0.46 \mathrm{mg} \mathrm{HC} / \mathrm{g}$ TOC and the low $\mathrm{S}_{2} / \mathrm{S}_{3}$ ratio $(0.5-1.24)$. The plot of the data on $\mathrm{S}_{1} / \mathrm{TOC} * 100$ vs depth (Figure 5C) and the low PI values further confirms that the studied core samples are overmature. At this stage, organic matter is thermally exhausted and has poor generative potential. The positioning of the data on HI vs OI diagram at the end of the evolutionary paths of kerogen types I, II, and III (Figure 8) is characteristic of overmaturity.

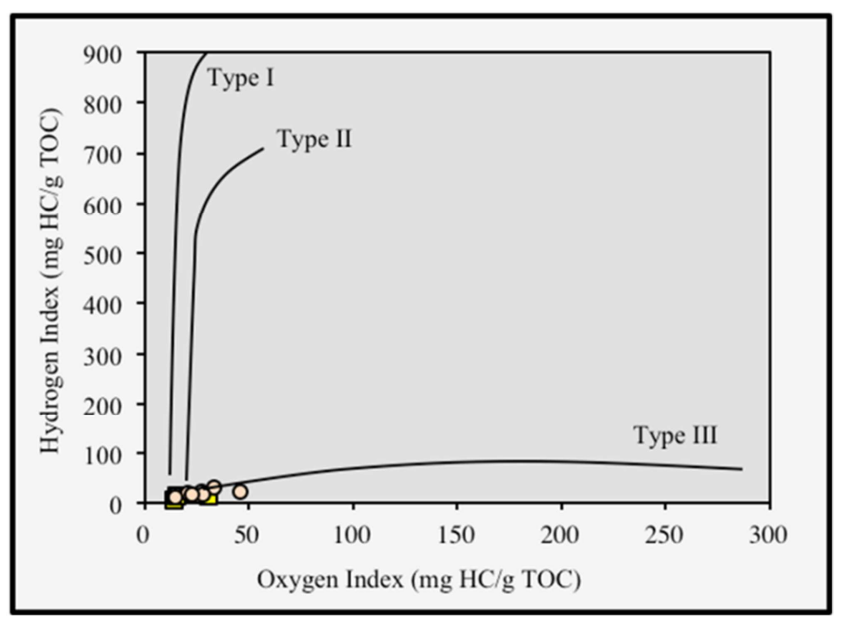

Figure 8. Plot HI vs OI in Nursery (brown circles) and Titusville (yellow square) cores of the Newark basin.

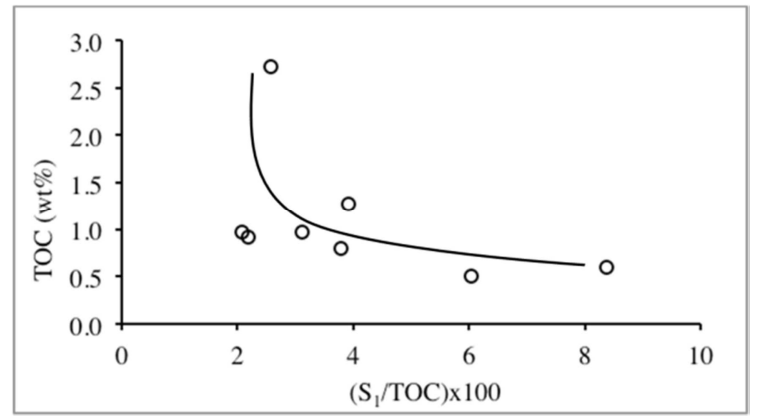

Figure 9. Plot TOC vs $\left(S_{I} / T O C\right) x 100$ in the Nursery core of the Newark basin. 
The pyrolyzable organic carbon $\left(\mathrm{PC}=\left(\left(\mathrm{S}_{1}+\mathrm{S}_{2}\right) / 10\right) \times 0.83\right)$ represents the portion of the TOC that is or can be converted to hydrocarbons. Residual carbon $(\mathrm{RC}=\mathrm{TOC}-\mathrm{PC})$ represents the non-pyrolyzable fraction of the TOC. The calculated $\mathrm{PC}$ values are very low ranging from 0.01 to 0.04 $\mathrm{wt} \%$ (avg. $=0.03 \mathrm{wt} \%$ ) and from 0.01 to $0.02 \mathrm{wt} \%$ (avg. $=$ $0.015 \mathrm{wt} \%$ ) for Nursery and Titusville, respectively. Conversely, the calculated RC values are high, varying between 0.49 and $2.68 \mathrm{wt} \%$ (avg. $=1.6 \mathrm{wt} \%$ ) and between 0.79 and $1.84 \mathrm{wt} \%$ (avg.= $1.3 \mathrm{wt} \%$ ) for Nursery and Titusville, respectively. The plot of RC vs TOC reveals a linear trend $(\mathrm{RC}=0.99$ TOC -0.008$)$ (Figure 10). This equation can be simplified to $\mathrm{RC} \approx \mathrm{TOC}$, indicating that almost all organic carbon left is the residual organic carbon and that there is no generative potential left in the analyzed samples.

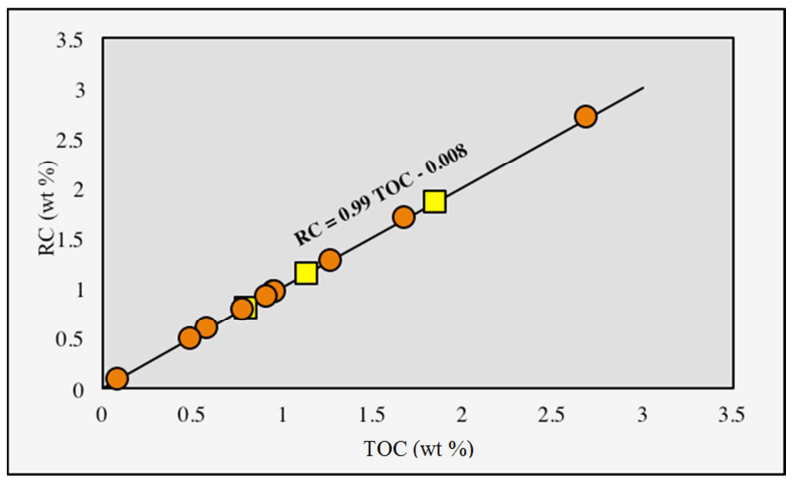

Figure 10. Total organic carbon (TOC) vs Residual carbon (RC) in the Nursery (brown circles) and Titusville (yellow squares) cores, Newark basin.

On the basis of the foregoing discussion, it can be concluded that the organic matter preserved in the Lockatong Formation is in the dry gas window, above the liquid oil generation window. The reactivation of the regional NE-SW-trending normal faults led to the active subsidence of the basin during the Late Triassic-early Jurassic [4]. The Lockatong Formation reached a maximum average depth of about $5300 \mathrm{~m}$ and a temperature of $210^{\circ} \mathrm{C}$ based on the depth-time-temperature burial curve (Figure 11) [15]. This subsidence buried the Lockatong Formation leading to the overmaturity of the organic matter preserved in this formation.

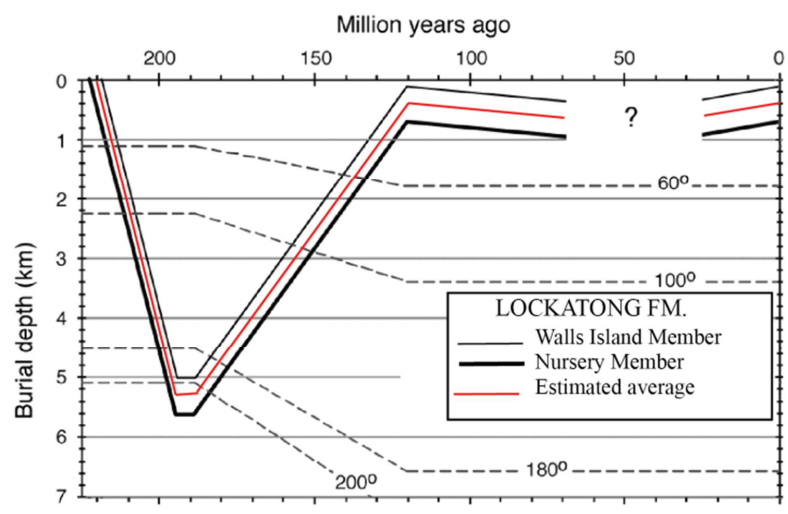

Figure 11. Depth-time-temperature burial curve of the Lockatong Formation with $35^{\circ} \mathrm{C} / \mathrm{km}$ (After [15]).
The overmaturity of the organic matter of the analyzed samples had tremendously reduced its hydrogen content, and thus Hydrogen Index. This renders the identification of the type of kerogen difficult. The identifying of the kerogen is, therefore, attempted using Zetaware software [18, 19]. With a maximum TOC of $2.72 \mathrm{wt} \%$, an estimated PI of $90 \%$ - given the overmaturity of $\mathrm{OM} \mathrm{-,} \mathrm{and} \mathrm{the} \mathrm{maximum} \mathrm{HI}$ of $32 \mathrm{mg}$ $\mathrm{HC} / \mathrm{mg}$ of rock, the calculated initial $\mathrm{HI}\left(\mathrm{HI}_{0}\right)$ value was about $320 \mathrm{mg} \mathrm{HC} / \mathrm{mg}$ rock. This initial HI value falls within the HI range of Type II/III kerogen. Hence, it is concluded that the organic matter preserved in the Lockatong Formation is of type II/III. This is consistent with the study carried on the basis of the solid-state nuclear magnetic resonance and the carbon stable isotope, which suggests that the organic matter preserved in this formation is of type II/III (lacustrinealgal debris and vascular plant debris) [5].

\section{Conclusions}

During the Late Triassic-early Jurassic time, the organic matter of the Lockatong Formation accumulated and preserved in an anoxic lacustrine environment. The TOC analysis of the black shale samples of this formation revealed that they may be fair to good source rock of hydrocarbons. The subsidence of the Newark basin during the Late Triassicearly Jurassic led to the burial and overmaturity of the organic matter. This subsidence was caused by the reactivation of the regional NE-SW-trending normal faults. Due to this overmaturity, determined by Rock-Eval pyrolysis, the organic matter of black shale samples from this formation have no more liquid hydrocarbon potential.

\section{Acknowledgements}

The author would like to thank Dr. Olsen of Columbia University, Dr. Browning and Dr. Kent both of Rutgers University for providing me the samples to complete this project. The author is also grateful to Dr. MaryAnn Malinconico of the Lafayette College, PA and to an anonymous reviewer for their constructive comments and suggestions that greatly improved the quality of this paper. The author also thanks the editor for handling this manuscript. This project benefited from a grant from the Geological Society of America to one of my undergraduate students.

\section{References}

[1] F. B. Van Houten (1964) Cyclic lacustrine sedimentation, Upper Triassic Lockatong Formation, New Jersey and adjacent Pennsylvania. In: Symposium on Cyclic Sedimentation. D. F. Merriam (eds.). Kansas Geological Survey Bulletin, 169, 497-531.

[2] P. E Olsen (1986) Milankovitch cycles in Early Mesozoic rift basins of Eastern North America provide physical stratigraphy and time scale for understanding basin evolution. Lamont (Newsletter), 13, 5-6. 
[3] N. M. Ratcliffe, W. C. Burton, R. M D'Angelo and J. K. Costain (1986) Low-angle extensional faulting, reactivated mylonites, and seismic reflection geometry of the Newark basin margin in eastern Pennsylvania. Geology, 14, 766-770.

[4] R. W. Schlische M. O. Withjack, and P. E Olsen (2003) Relative timing of CAMP, rifting, continental breakup, and basin inversion: Tectonic significance. In: The Central Atlantic Magmatic Province, Insights from fragments of Pangea. W. E. Hames J. G. McHone P. R. Renne and C. Ruppel (eds.). American Geophysical Union, Geophysical Monograph 136, pp. 33-59.

[5] B. J Katz C. R. Robison T. Jorjorian and F. D Foley (1988) The level of organic maturity within the Newark basin and its associated implications. In: Triassic-Jurassic Rifting, Continental Breakup and the Origin of the Atlantic Ocean and Passive Margins. W. Manspeizer (eds.). Part B: Elsevier, Amsterdam, The Netherlands, Developments in Geotectonics, v. 22, pp. 683-696.

[6] M. L. Malinconico (2002) Lacustrine organic sedimentation, organic metamorphism, and thermal history of selected early Mesozoic Newark supergroup basins, eastern U.S.A. Columbia University Ph.D. dissertation, New York, New York, 419 p.

[7] L. M. Pratt A. K. Vuletich and T. A. Daws (1985) Organic geochemistry and thermal maturity of organic matter in rocks of Newark Supergroup. In: Proceedings of a workshop on the Eastern Mesozoic Basins Program. U.S. Geological Survey Circular, 946, pp. 74-78.

[8] P. E. Olsen (1980) Triassic and Jurassic formations of the Newark basin. In: Field Studies in New Jersey Geology and Guide to Field Trips. Manspeizer, W. (eds.) 52nd Annual Meeting, New York State Geological Association, Newark College of Arts and Sciences, Newark, Rutgers University, pp. 2-39.

[9] R. D. Nance and U Linneman (2008) The Rheic Ocean: Origin, evolution, and significance. GSA Today, 18, 4-12.

[10] W. Manspeizer (1988) Triassic-Jurassic rifting and opening of the Atlantic: An overview. In: Triassic- Jurassic rifting, continental breakup, and the formation of the Atlantic Ocean and passive margins. In: W. Manspeizer (eds.). Part A: Elsevier. Amsterdam, Netherlands, Elsevier, pp. 41-79.
[11] R. W. Schlische, and P. E. Olsen (1990) Quantitative filling model for continental extensional basins with applications to early Mesozoic rifts of eastern North America. Journal of Geology, 98, 135-155.

[12] M. Serfes G. Herman, S Spayd and J Reinfelder (2010) Sources, mobilization and transport of arsenic in groundwater in the Passaic and Lockatong Formations of the Newark basin, New Jersey. New Jersey Geological Society Bulletin, 77, pp. $1-40$.

[13] M. O. Withjack R. W. Schlische, and P. E. Olsen (1998) Diachronous rifting, drifting, and inversion on the passive margin of central eastern North America: An analog for other passive margins. American Association of Petroleum Geologists Bulletin, v. 82, no. 5A, pp. 817-835.

[14] J. Espitalié G. Deroo, and F. Marquis (1985) La pyrolyse Rock-Eval et ses applications. $2^{\text {ème }}$ partie. Revue de l'Institut Français du Pétrole, v. 40, pp. 755-784

[15] M. L. Malinconico (2010) Synrift to early postrift basin-scale groundwater history of the Newark basin based on surface and borehole vitrinite reflectance data. In: Herman, G. C., and M. E. Serfes (eds.). Contributions to the Geology and Hydrogeology of the Newark Basin, N. J. Geological Survey Bulletin 77, Chapter C., pp. 1-38.

[16] L. Rddad (2017) Fixation and redistribution of arsenic of the Lockatong Formation, Newark basin, USA: Implications for the quality of groundwater. Atlantic Geology Journal, 53, 253 -268 .

[17] K. E. Peters C. C. Walters, and J. M. Moldowan (2005) The biomarker guide, second edition, volume I, biomarkers and isotopes in petroleum systems and human history. United Kingdom, Cambridge University Press, 476 p.

[18] A. S. Pepper and P. J. Corvi (1995a) Simple kinetic models of petroleum formation. Part I: oil and gas generation from kerogen. Marine and Petroleum Geology, 12, 291-319.

[19] A. S. Pepper and P. J. Corvi (1995b) Simple kinetic models of petroleum formation. Part III: Modeling an open system. Marine and Petroleum Geology, 12, 417-452. 